\title{
Canopy Architecture After Selective Logging in a Secondary Atlantic Rainforest in Brazil
}

\author{
Daniel Augusto da Silva ${ }^{1}$ (D), Alexander Christian Vibrans ${ }^{1}$ \\ ${ }^{1}$ Universidade de Blumenau - FURB, Blumenau/SC, Brasil
}

\begin{abstract}
Sustainable forest management promotes financial revenues while keeping the forest cover and environmental services. Nevertheless, the logging operation causes changes in the forest and canopy horizontal and vertical structure. Our objective is to evaluate the changes in the forest canopy and its consequences to the forest management, following logging in a secondary Atlantic Rainforest. We used hemispherical photography to determine the Canopy Openness (CO), Leaf Area Index (LAI) and the radiation absorption (fAPAR) in nine experimental plots before and after logging. We did not find a clear correlation between the forest horizontal structure and the canopy architecture. Despite this, there was an increase in CO and decrease in LAI and fAPAR after logging. The variation in CO and FAPAR were affected by logging intensity, but LAI did not show the same pattern. We suggest a conservative maximum logging intensity of $30 \%$ of the basal area and tree density.
\end{abstract}

Keywords: forest management, hemispherical photography, leaf area index, canopy openness, fAPAR. 


\section{INTRODUCTION}

Tropical forests are key components of the biosphere. They accommodate more than half of the forest carbon of the planet, of which $42 \%$ is stored in live biomass. Secondary forests represent an important $\mathrm{CO}_{2}$ sink, absorbing $1.7 \pm 0.5 \mathrm{Pg} \mathrm{C}_{\text {year }}{ }^{-1}$ between 2000 and 2007 (Pan et al., 2011). Most of Santa Catarina's native vegetation is composed of small fragments of secondary forests with less than 50 ha, representing about $40 \%$ of the original forest cover of the state (Vibrans et al., 2013). Moreover, they are under big pressure to convert to other land uses, in part, because of the low value attributed to native forests (Siminski \& Fantini, 2010). In this context, assigning value to the forest through sustainable management may become an important strategy of environmental conservation (Rockwell et al., 2007). Managed forests maintain much of the environmental services and forests biodiversity (e.g. Putz et al., 2012; Bicknell et al., 2014; Luke et al., 2017). Therefore, they have a very high ecosystem value in relation to other land uses, such as agriculture and reforestation (Edwards et al., 2014).

At the Atlantic Forest Domain, the Brazilian legislation is very brief and restrictive in terms of selective logging and forest management. The Decree 6660/08 (Brasil, 2008) determines the possibilities of selective logging in the Atlantic Forest domain. The legislation allows selective logging of pioneer species in secondary forests in the "middle stage" of regeneration if the pioneer species represents more than $60 \%$ of the local trees with diameter at breast height (DHB) $\geq 5 \mathrm{~cm}$. Still according to the decree, the maximum logging intensity cannot change the stand's characteristics, and measures to minimize impacts must be taken. Forests at advanced stage of regeneration or mature cannot be subject of selective logging, as well as pioneer species that characterize mature forests, like Araucaria angustifolia, or endangered species (Brasil, 2008).

The selective logging may cause changes in canopy architecture, generating greater canopy openness (CO) at different levels, depending of the intensity of logging. $\mathrm{CO}$ is a determining factor in the forest microclimate, especially relating to light amount and quality available in the understory (Hardwick et al., 2015). It is one of the main factors on the floristic composition of natural regeneration (Jurinitz et al., 2013), along with the presence of litter, soil revolving, and distance of mother trees (Karsten et al., 2013; Corrià-Ainslie et al., 2015). Thus, logging should occur in an intensity to provide a CO that allows the regeneration of economic interest species without an intense colonization by pioneer species.

Canopy openness is defined by the percentage of sky seen throughout the hemisphere from a single point below the canopy (Gower et al., 1999). From obtaining the $\mathrm{CO}$ measure at different zenith angles, it is also possible to estimate leaf area index (LAI) and the fraction of photosynthetically active absorbed radiation (fAPAR). LAI (unitless) is defined as half of the total leaf area per unit of horizontal soil surface area (Chen \& Black, 1992). fAPAR (unitless) is defined as the fraction of the total photosynthetically active radiation absorbed by the canopy (arboreal stratum), which may also include understory and herb layer, depending of the height of measurement (Gower et al., 1999). These factors influence several ecosystem processes, such as light availability, rainfall interception and $\mathrm{CO}_{2}$ absorption (Schleppi et al., 2007), and are commonly used in $\mathrm{CO}_{2}$ and climate models (Zheng \& Moskal 2009; Piayda et al., 2015).

In forest management areas, it is usual to observe a large increase in $\mathrm{CO}$ after the logging, both in areas with Reduced Impact Logging (RIL) and areas with Conventional Logging (CL) (Schulze \& Zweede 2006). $\mathrm{CO}$ tends to increase with the logging intensity and in rugged terrain (Guitet et al., 2012). Moreover, areas with RIL generally show less change in the $\mathrm{CO}$ in relation to CL areas with similar cut intensity (Schulze \& Zweede 2006). Therefore, the different levels of logging intensity and canopy openness have direct influence on the regeneration that will occur (Karsten et al., 2013) and consequently, on the future floristic composition of the forest (Putz et al., 2008).

Our main objective is to quantify the changes in canopy architecture after the selective logging in a secondary Atlantic Rainforest in Santa Catarina's north coast. The specific objectives are: a) to identify the relationship between the forest structure and canopy architecture; and b) to quantify the relationship between logging intensity and changes in the canopy architecture. The working hypotheses are that the $\mathrm{CO}$ increases as both LAI and fAPAR decrease following 
logging, and that these changes vary according to the logging intensity applied. We aim to contribute to the understanding of the selective logging consequences on Atlantic secondary rainforests, and to suggest a baseline logging intensity based on canopy parameters. To do so, we present a case study regarding logging influence on the canopy at a representative secondary forest in southern Brazil.

\section{MATERIAL AND METHODS}

\subsection{Study area}

The study was conducted in a secondary subtropical rainforest (Oliveira, 2009) within a 42 -ha farm in the northwest of the Estate of Santa Catarina (26 $32^{\prime} 10^{\prime \prime} \mathrm{S}$ and $49^{\circ} 02^{\prime} 38^{\prime \prime} \mathrm{O}$, Figure 1 ), with altitude ranging from 160 to 500 m.a.s.l. According to the Köppen classification, the climate in the region is Cfa - mesothermic subtropical humid with a hot summer without a dry season (Alvares et al., 2013). The study site is in a hilly terrain with slopes ranging from $10 \%$ to $40 \%$. The soils in the region are predominantly cambisol.

The study forest was originated by an enrichment plantation in an intensively exploited area in 1978, in which saplings of Miconia cinnamomifolia, Hieronyma alchorneoides and Nectandra spp. were planted. At that time, the area was composed mostly by pasture with some patches of forest in the initial phases of development. The only silvicultural treatment made to the forest was the mowing of the herbaceous vegetation in the first five years after plantation. Since then, the forest has grown with small and unplanned intervention, like eventual cutting of Euterpe edulis for heart-of-palm production and woody species for timber uses. Assessing its structure and species composition, one can verify that the forest within the study area represents a typical secondary rain forest, although most forests of the surrounding area were generated by ecological succession after abandonment of agriculture and pasture areas, and not by enrichment plantations.

\subsection{Experimental design and data collection}

We randomly placed 12 fixed squares experimental plots (EP) of 3,600 $\mathrm{m}^{2}$ with useful area of $1,600 \mathrm{~m}^{2}$ in the center of the experimental plot, subdivided into 16 subunits of $100 \mathrm{~m}^{2}$. The measurements of forest structure and hemispherical photographs were recorded within the "useful area" of the EP, while the logging operation took place in the entire EP. From these, we selected nine EP to receive the selective logging. The experimental treatment consisted on the application of different logging intensities (see section 2.3). We discarded four subunits from the survey due to a tree falling before the start of measurements, totaling 140 subunits $\left(100 \mathrm{~m}^{2}\right)$ measured.
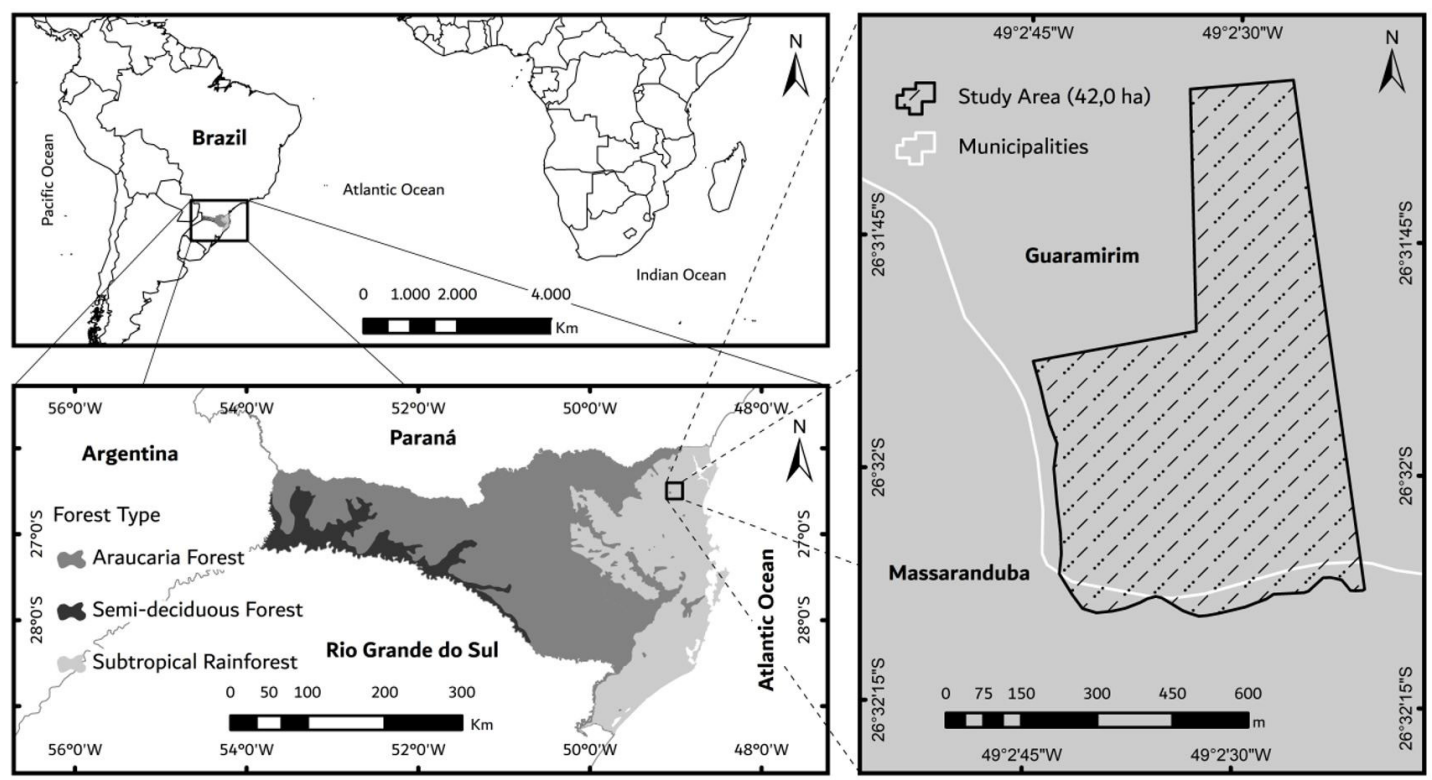

Figure 1. Study location in Santa Catarina state. 
Hemispherical photographs are an efficient way to estimate $\mathrm{CO}$, which allows the projection of a hemisphere in a surface assigning a system of angular coordinates to the image (Rich, 1990). The hemispherical photographs were taken with a DSLR Nikon D3100 camera and a $10.5 \mathrm{~mm}$ Nikon Fish-eye Nikkor lens, attached to a tripod. The photographs were taken in the center of each sample subunit, with the lens leveled at 1.30 meters from the ground and the upper part of the camera facing the magnetic North, according to the methodology suggested by Rich (1990). To minimize the anisotropy of solar rays and the dispersion fluxes in the digital image, the photos were taken on cloudy days, or on clear sky days in the early morning (Rich, 1990; Gonsamo \& Pellikka 2009), using the camera's automatic exposure. Photographs were taken before and after logging, at an interval that did not exceed six months before and two months after the cut, to reduce the effect of time and growth of the vegetation in the analyses. Seasonality was not a concern, since the great majority of the species of the local forest do not lose their leaves in the winter.

Table 1. Minimum cutting diameter (MCD) for logging in a secondary forest in the northwest of Santa Catarina.

\begin{tabular}{ll}
\multicolumn{1}{c}{ Classes } & MCD \\
\hline Tree species without timber potential & $>5 \mathrm{~cm}$ \\
\hline $\begin{array}{l}\text { Pioneer and early secondary species with } \\
\text { timber potential }\end{array}$ & $>25 \mathrm{~cm}$ \\
\hline Late secondary species with timber potential & $>35 \mathrm{~cm}$ \\
Climax species with timber potential & $>40 \mathrm{~cm}$ \\
\hline
\end{tabular}

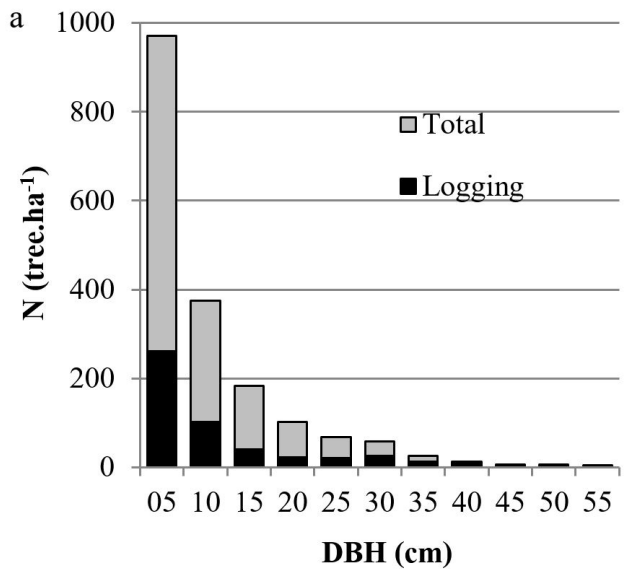

The tree structure data was determined for the useful area of the EP and were obtained through forest inventories executed before and after logging, at a similar time interval from the photographs. In them, we measured the Diameter at Breast Height (DBH) and estimated the height with clinometer of every tree with $\mathrm{DBH} \geq 5 \mathrm{~cm}$. The trees positions in the $\mathrm{EP}$ were recorded with " $\mathrm{x} y$ " coordinates. Trees were identified at species level by botanist at the field or afterward, at the herbarium. We, then, determined the density $(\mathrm{N})$ and basal area $(\mathrm{G})$ of the forest and the logging intensity applied to each EP and subunit.

\subsection{Logging}

The logging was performed on the total area of the EP and trees were pre-selected according to pre-logging inventory information. The selection considered timber potential, ecological group, minimum cutting diameter (MCD, Table 1), and species abundance, giving preference to logging commercial species with greater number of individuals in the EPs. We also selected trees with timber potential under the MCD when those trees were senile or when there was severe damage to the bole or crown. Climax species with low density locally were preserved from logging. We distributed the logging as homogeneously as possible throughout the EP and between the diametric classes (Figure 2a), with planned intensities varying between $20 \%$ and $60 \%$ of the EP's basal area removed.

After the logging of pre-selected tress and computation of the corresponding basal area removed, we returned

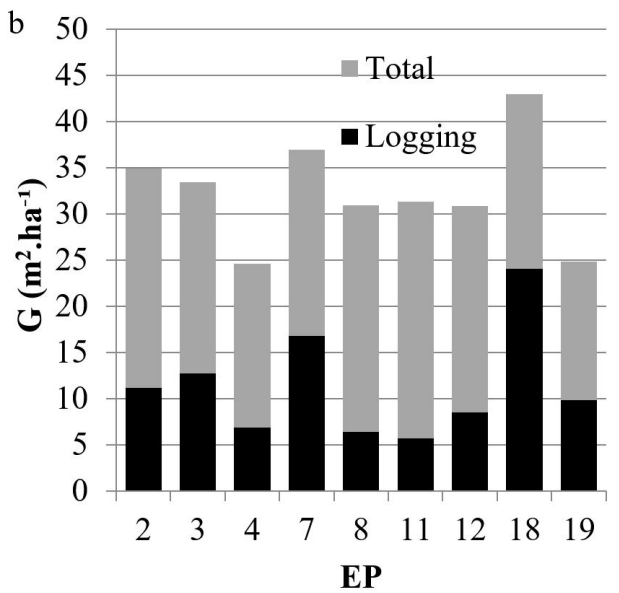

Figure 2. Diameter distribution of the original stand and felled trees (a) and logging intensities (b) at the EP level in a secondary forest in the northwest of Santa Catarina. 
to the EP to complement the logging. Trees found with the stem broken or with irreversible damages, canopy completely broken, or totally fallen, were then felled and extracted from the forest. Thus, the final logging intensity was given by the sum of pre-selected trees with the trees extracted for presenting irreversible damages. In practice the logging intensities varied between $18 \%$ and $56 \%$ of the basal area at the EP level (Figure 2b), while at the subunit level the logging intensity ranged from $0 \%$ to $98 \%$ of the basal area.

The logging was carried out in semi-mechanized way, the felling was executed with chainsaw and the extraction with tractor equipped with winch. The trees were extracted with the tree-length system, with the debranching done inside the forest. Twigs and log parts with diameter less than what is used for sawmills was extracted as firewood.

\subsection{Data analysis}

The hemispherical photographs were processed using the software CAN_EYE v6.3.8 (Weiss \& Baret, 2010), with supervised classification determining the sky and vegetation strata. The classification was then used as the basis for the calculation of CO, LAI and fAPAR. To calculate the fAPAR, only diffuse radiation was considered, since it was more stable throughout the year.
We verified the normality of the data through visual analysis of the qqplot graphs and the presence of outliers through the Cleveland's dotplot, according to methodology suggested by Zuur et al. (2010). For the comparisons between the canopy parameters before and after logging, we choose the Wilcoxon signed rank non-parametric test, because of the small number of repetitions and non-normal distribution of the data.

To verify the existence of a relation between the horizontal structure and the structure of the canopy before and after logging, we used Pearson correlations. In each correlation analyses we used a horizontal structure variable (basal area or density) and a canopy variable (CO, LAI or fAPAR). To determine the interference of the logging intensity on the canopy structure, we used a simple linear regression containing the percentage of basal area or density felled as independent variables and the canopy parameters after logging as dependent variables. All analyses were performed using the $\mathrm{R}$ environment, with significance of $p=0.05$.

\section{RESULTS}

The average forest $\mathrm{CO}$ increased from $8.4 \%$ before, to $21.6 \%$ after logging (Figure $3 \mathrm{a}$ ), which resulted in statistically significant difference $(\mathrm{W}=45 ; \mathrm{n}=9 ; \mathrm{p}<0.01$ ). The same way, the reduction from 0.93 to 0.81 in fAPAR was statistically significant $(\mathrm{W}=45 ; \mathrm{n}=9 ; \mathrm{p}<0.01$,
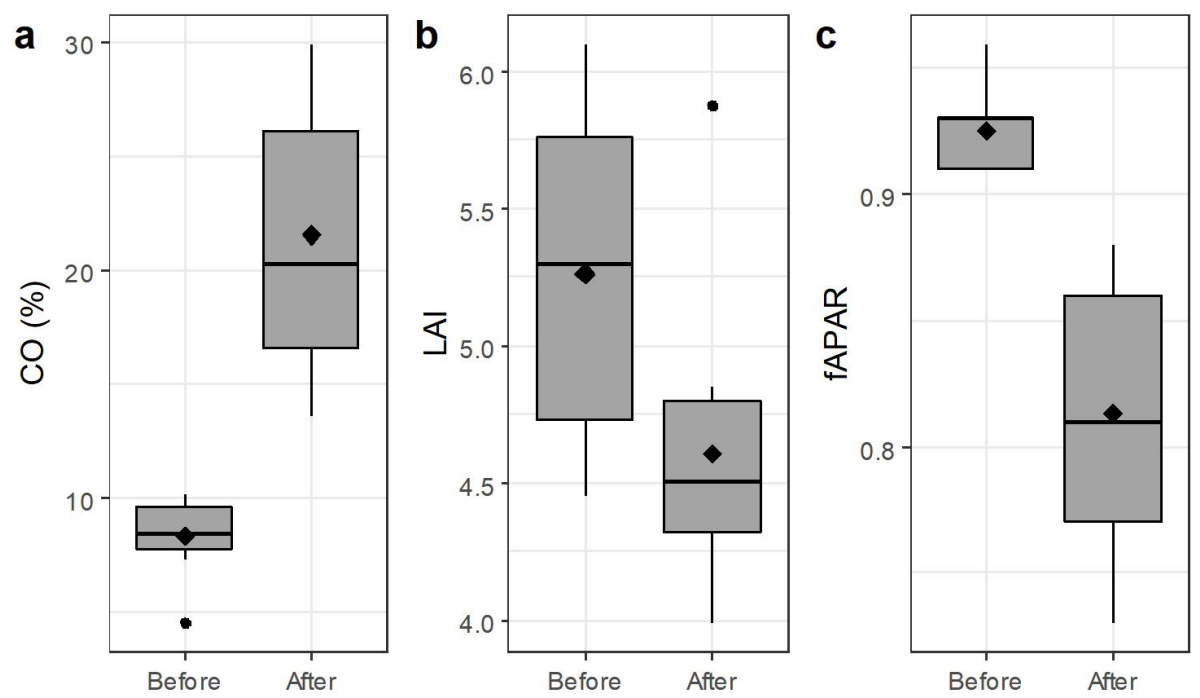

Figure 3. (a) Canopy Opening (CO), (b) Leaf Area Index (LAI) and (c) fraction of absorbed photosynthetically active radiation (fAPAR) before and after logging in a secondary forest in the northwest of Santa Catarina. 
Figure 3c). The average LAI reduction, from 5.3 to 4.5 , was not significant at the tested level in a first analysis ( $\mathrm{W}=37 ; \mathrm{n}=9 ; \mathrm{p}=0.09$ ), however, the difference becomes significant when we exclude an outlier value from the analysis $(\mathrm{W}=32 ; \mathrm{n}=8 ; \mathrm{p}=0.05$, Figure $3 \mathrm{~b}$ ). This outlier value was derived in part from the presence of understory individuals just above the camera lens in some of the photographs in the EP, which caused an unrealistic increase in LAI. We chose to present the results with and without this value.

Both $\mathrm{CO}$ and fAPAR showed bigger data dispersion after logging (Figure 3). CO had a standard deviation of $1.8 \%$ before logging and $5.8 \%$ after the operation, and fAPAR had 0.016 and 0.051 , respectively. On the other hand, LAI presented less dispersed data after logging, with a standard deviation of 5 and 4.5 before and after logging, respectively. None of the canopy parameters showed a statistically significant correlation with the forest horizontal structure before or after logging (Table 2). Before logging, $\mathrm{CO}$ had a moderate correlation with the forest basal area, but the relation was not significant at the tested level $(p=0.1)$. LAI and fAPAR had weaker correlations, especially after logging. The correlations with forest density were more consistent among the canopy parameters before logging, presenting similar values, although very low. After logging, $\mathrm{CO}$ and fAPAR increased their correlation with the forest tree density, but still not significant at the tested level.

The logging intensity, described by the percentage of trees extracted, presented a statistically significant coefficient of determination for CO and fAPAR (Figure 4).

About $41 \%$ of the $\mathrm{CO}$ and $35 \%$ of fAPAR variation after logging were explained by the intervention intensity. Contradictorily, LAI did not show a significant relation with the logging intensity, even with the outlier value exclusion. The logging intensity described by the percentage of basal area extracted was not successful in explaining the canopy structure variation after logging (data not shown), that is, no regression presented a statistically significant coefficient of determination at the tested level. Figure 5 shows the interactions between the logging intensity (number of trees and basal area) and the canopy architecture after the intervention in the experimental plots.

Table 2. Correlation coefficient between basal area $(G)$, density $(N)$ and the canopy parameters in a secondary forest before and after the logging in northwest Santa Catarina.

\begin{tabular}{|c|c|c|c|c|c|c|c|c|}
\hline & \multicolumn{4}{|c|}{$G\left(m^{2} h a^{-1}\right)$} & \multicolumn{4}{|c|}{$\mathbf{N}\left(\right.$ tree.ha $\left.^{-1}\right)$} \\
\hline & \multicolumn{2}{|c|}{ Before } & \multicolumn{2}{|c|}{ After } & \multicolumn{2}{|c|}{ Before } & \multicolumn{2}{|c|}{ After } \\
\hline & $\mathbf{r}$ & $\rho$ & $\mathbf{r}$ & $\rho$ & $\mathbf{r}$ & $\rho$ & $\mathbf{r}$ & $\rho$ \\
\hline $\mathrm{CO}$ & -0.58 & 0.1 & -0.14 & 0.71 & 0.17 & 0.66 & -0.59 & 0.09 \\
\hline LAI & 0.27 & 0.47 & $0.24(0.23)$ & $0.52(0.57)$ & 0.11 & 0.76 & $0.12(0.26)$ & $0.75(0.53)$ \\
\hline fAPAR & 0.17 & 0.67 & 0.13 & 0.74 & 0.25 & 0.52 & 0.59 & 0.09 \\
\hline
\end{tabular}

Values between brackets represent the correlation excluding the outlier.
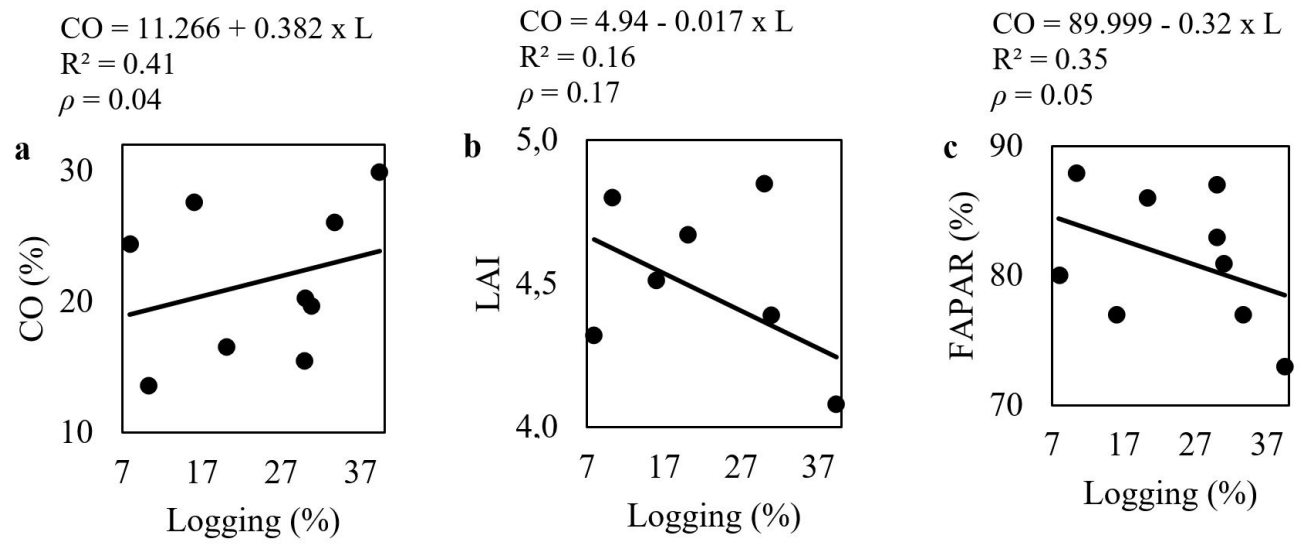

Figure 4. Relation between (a) CO (canopy opening), (b) LAI (leaf area index) and (c) fAPAR (fraction of absorbed photosynthetic active radiation) after logging and logging intensity (\% of trees felled, L) in a secondary forest northwest Santa Catarina. Values of LAI excluding the outlier. 


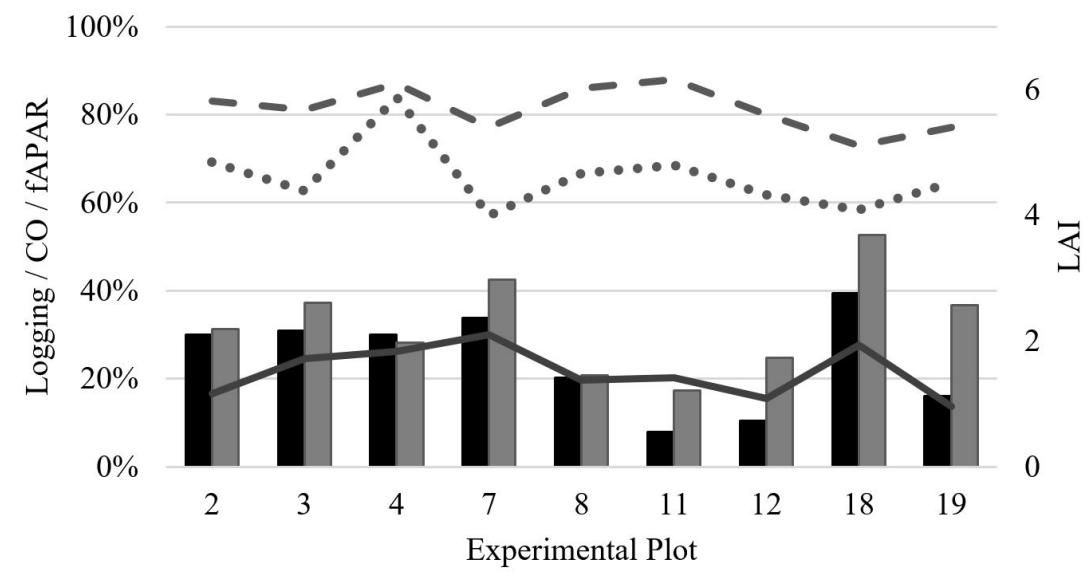

Logging $(\mathrm{N})$

Logging $(\mathrm{G})$

$\mathrm{CO}-$ - fAPAR $\cdots \cdot \cdot \mathrm{LAI}$

Figure 5. Interaction between logging intensity (percentage) and canopy architecture (fAPAR values transformed to percentage, for better visualization) after the intervention on the EP in a secondary forest northwest Santa Catarina.

\section{DISCUSSION}

Canopy architecture can be used to identify degradation gradients, and link forest structure to environmental parameters (e.g. Pfeifer et al., 2016; Pfeifer et al., 2018), in addition to have a strong influence in forest microclimate (Hardwick et al., 2015). Our results before logging showed low data dispersion in both $\mathrm{CO}$ and fAPAR, but, contradictorily, LAI showed great data dispersion. If the first two parameters suggest a more or less homogeneous light environment inside the forest, the third one suggests the existence of a heterogeneous distribution of canopy openings. The results demonstrate the inherently complex architecture of tropical forest canopies, and all three variables are coherent with preliminary results from the Santa Catarina Forest Inventory, that shows values of $\mathrm{CO}$ varying between $3.5 \%$ and $26.1 \%$ for secondary rainforests. After logging, we observed an inversion of this pattern, with $\mathrm{CO}$ and fAPAR showing an increase in data dispersion and a decrease in LAI dispersion. This change represents the variation in logging intensities applied, which created areas with very high $\mathrm{CO}$ and areas that retained a $\mathrm{CO}$ similar to the pre-logging state. In counterpoint, the decrease of tree layers and simplification of the vertical structure of the forest causes a consequent decrease in LAI dispersion.

The study area operational and topographic conditions favor the appearance of impacts from the logging. The absence of RIL techniques, high logging intensity and rugged relief, have potential to increase the magnitude of the impacts generated by the intervention (Van Der Hout, 1999; Guitet et al., 2012). Besides representing a relevant part of the remaining tropical forests, very little is known about secondary forests management, even less about its impact on the canopy architecture, making it difficult to compare our results with other forest management sites. Even so, our CO measurements after logging was similar to those observed in forest management areas in mature tropical forests, which generally occur in flatter areas and applies much lower logging intensities using Reduced Impact Logging techniques (Van Der Hout, 1999; Guitet et al., 2012). Much of this similarity can be explained by the difference in size of the trees felled on both situation; while in our site we felled a large number of small trees, in primary forests it is usually felled a small number of large trees. The size of the tree felled has an obvious positive relation with the $\mathrm{CO}$, even though in our site this relation was supplanted by the high logging intensity.

The logging intensity had an influence on the $\mathrm{CO}$ variation after the intervention, confirming what was observed in other management areas, that higher intensity logging produces larger canopy openings (Van Der Hout, 1999; Guitet et al., 2012). In areas with logging intensity and spatial distribution controlled, Van Der Hout (1999) observed a correlation coefficient 
as high as $R^{2}=0.92$, showing a clear relation between intensity, in this case basal area felled, and CO after the intervention. In our study, only the number of trees felled had a significant determination coefficient on the variation in $\mathrm{CO}$, while the basal area was not significant. An explanation for this result is the accounting in the logging intensity of trees from the understory, which make a large part of the felled trees (Figure 1), but represent only a small portion of the total basal area. Although the reduced DBH and crown, these individuals may cause a considerable influence on $\mathrm{CO}$ and, this way, weaken its relationship with the basal area and strengthen with the number of trees felled.

Factors such as the spatial distribution, size and architecture of felled trees also influence the canopy openness. In the study area, we observed a high variation on the spatial distribution and on the sizes of the felled trees, which contributed to the large variation in $\mathrm{CO}$ after the intervention, as can be observed in Figures 3 and 5. In areas with concentration of marked trees for logging, for example, a clearing opened by the felling of a tree can be used for the felling of others, not causing more canopy opening. This situation was quite common in the study area because of the high density of trees felled. In addition, trees with the same basal area can cause damages to distinct extensions, depending on the shape and size of its crown. These added factors influence negatively on the correlation between logging intensity and $\mathrm{CO}$ after the intervention. Our methodology did not allow us to measure variables such as crown size or felling location and direction of individual trees. The hilly terrain and small area of the farm did not allow for bigger and more numerous EPs. These added factors also decrease our capability to capture the relationship between logging intensity and changes in the canopy structure and must be taken into account when interpreting the results of the study.

Logging intensity had influence on fAPAR, but it did not have on LAI. We expect this result analyzing the data dispersion of the variables after logging. It is possible to observe a decreasing tendency in LAI with higher logging intensities, but not enough to be statistically significant at the level tested. We suspect there are two main causes influencing this result: the large heterogeneity of LAI before logging, and the lack of slope correction in LAI estimation. In terrains with rugged and variable relief, like in our study site, the slope can play an important role in LAI estimation (Walter \& Torquebiau, 2000), potentially masking the results. Nevertheless, we believe that with more repetitions and/or larger plots we would get a similar result as the other variables.

The absence of correlation of these parameters with the forest horizontal structure may be a reflection of the high biodiversity and consequent variety in architectures and arrangements of a tropical forests canopy. The increased CO and decreased LAI caused by the logging increases the luminosity and temperature and decrease the humidity in the understory (Hardwick et al., 2015), as well as decrease the $\mathrm{CO}_{2}$ absorption rates (Miller et al., 2011). These changes, however, tend to be reversed in the first years after logging, due to the quick colonization of clearings and high growth rates observed on the regeneration (Medjibe et al., 2011). Moreover, the greater heterogeneity in the forest microclimate created by the different logging intensities allows different groups of species to colonize these areas, and, as a side effect, can create an increase in local biodiversity (Karsten et al., 2013).

From a management point of view, it is important to determine a maximum logging intensity to increase the productivity without bringing the forest back to an initial stage. The strong influence the canopy architecture has on the forest microclimate, and the influence the logging intensity has on the canopy, allow us to suggest an ideal logging intensity for the desired light conditions in the understory. In the area, the increase in canopy opening causes an increase in pioneer species regeneration, with $\mathrm{CO}$ as low as $20 \%$ already showing a considerable effect on the pioneer's density (data not shown). In terms of logging intensity, this means that limiting the logging to $30 \%$ in both basal area and density (see Figure 5) may hold the pioneer species colonization and favor the secondary species regeneration with the increase in light availability in the understory.

\section{CONCLUSIONS}

The main conclusions of our study are: the canopy parameters were not correlated to the forest horizontal structure before or after logging; CO significantly increases, and fAPAR decreases, after logging according to the logging intensity; LAI decreases after logging, but its link with the logging intensity is weaker than the others. We suggest a conservative maximum logging intensity of $30 \%$ of the basal area and density, in order to keep the $\mathrm{CO}$ low enough to not induce an over-colonization of pioneer species. 
The study provides a baseline of impacts caused by the logging operation on the canopy architecture. The monitoring of the area will allow us to verify the dynamics of the canopy architecture in the years following the intervention and clarify the ecological consequences of the impacts and the level of impact that is acceptable for a given sustainability goal.

\section{ACKNOWLEDGEMENTS}

The authors thank the owners of the study site, Bisewski Family, for access to their forest and for support of timber harvesting, FATMA for the management authorization and the Forest Engineers Geferson Piazza, Heitor Felipe Ulller and Aline Klitzke for the help in the data collection. We thank the The Madeira Nativa project, coordinated by professor Alfredo Fantini and funded by FAPESC (Award 18689/2009-9) from 2009 to 2014. The first author is grateful to FAPESC and CNPq for the master degree grant, the second author is being supported by CNPq research grant 312075/2013-8.

\section{SUBMISSION STATUS}

Received: 3 sep., 2018

Accepted: 22 aug., 2019

\section{CORRESPONDENCE TO}

\section{Daniel Augusto da Silva}

Programa de Pós-graduação em Engenharia Florestal, Universidade de Blumenau - FURB, Rua São Paulo, 3250, CEP 893-080, Blumenau, SC, Brasil e-mail: danielaugusto@furb.br, daneflorestal@ gmail.com

\section{FINANCIAL SUPPORT}

FAPESC (Award 18689/2009-9); CNPq research grant 312075/2013-8.

\section{REFERENCES}

Alvares CA, Stape JL, Sentelhas PC, Gonçalves JLM, Sparovek G. Köppen's climate classification map for Brazil. Meteorologische Zeitschrift (Berlin) 2013; 22(6): 711-728. http://dx.doi.org/10.1127/0941-2948/2013/0507.
Bicknell JE, Struebig MJ, Edwards DP, Davies ZG. Improved timber harvest techniques maintain biodiversity in tropical forests. Current Biology 2014; 24(23): 1119-1120. http:// dx.doi.org/10.1016/j.cub.2014.10.067. PMid:25465328.

Brasil. Decreto no 6660, de 21 de novembro de 2008. Regulamenta dispositivos da Lei no 11.428, de 22 de dezembro de 2006, que dispõe sobre a utilização e proteção da vegetação nativa do Bioma Mata Atlântica. Diário Oficial da República Federativa do Brasil, Brasília, DF (2008 nov. 21).

Chen JM, Black TA. Foliage area and architecture of plant canopies from sunfleck size distributions. Agricultural and Forest Meteorology 1992; 60(3-4): 249-266. http://dx.doi. org/10.1016/0168-1923(92)90040-B.

Corrià-Ainslie R, Camarero JJ, Toledo M. Environmental heterogeneity and dispersal processes influence postlogging seedling establishment in a Chiquitano dry tropical forest. Forest Ecology and Management 2015; 349: 122-133. http://dx.doi.org/10.1016/j.foreco.2015.03.033.

Edwards DP, Gilroy JJ, Woodcock P, Edwards FA, Larsen $\mathrm{TH}$, Andrews DJR et al. Land-sharing versus land-sparing logging: reconciling timber extraction with biodiversity conservation. Global Change Biology 2014; 20(1): 183-191. http://dx.doi.org/10.1111/gcb.12353. PMid:23955803.

Gonsamo A, Pellikka P. A new look at top-of-canopy gap fraction measurements from high-resolution airborne imagery. EARSeL eProceedings 2009; 8(1): 64-74.

Gower ST, Kucharik CJ, Norman JM. Direct and indirect estimation of leaf area index, fAPAR, and Net primary production of terrestrial ecosystems. Remote Sensing of Environment 1999; 70(1): 29-51. http://dx.doi.org/10.1016/ S0034-4257(99)00056-5.

Guitet S, Pithon S, Brunaux O, Jubelin G, Gond V. Impacts of logging on the canopy and the consequences for forest management in French Guiana. Forest Ecology and Management 2012; 277: 124-131. http://dx.doi. org/10.1016/j.foreco.2012.04.011.

Hardwick SR, Toumi R, Pfeifer M, Turner EC, Nilus R, Ewers RM. The relationship between leaf area index and microclimate in tropical forest and oil palm plantation: forest disturbance drives changes in microclimate. Agricultural and Forest Meteorology 2015; 201: 187-195. http://dx.doi. org/10.1016/j.agrformet.2014.11.010. PMid:28148995.

Jurinitz CF, Oliveira AA, Bruna EM. Abiotic and biotic influences on early-stage survival in two shade-tolerant tree species in Brazil's Atlantic Forest. Biotropica 2013; 45(6): 728-736. http://dx.doi.org/10.1111/btp.12058.

Karsten RJ, Jovanovic M, Meilby H, Perales E, Reynel C. Regeneration in canopy gaps of tierra-firme forest in the Peruvian Amazon: comparing reduced impact logging and natural, unmanaged forests. Forest Ecology and Management 2013; 310: 663-671. http://dx.doi. org/10.1016/j.foreco.2013.09.006. 
Luke SH, Barclay H, Bidin K, Chey VK, Ewers RM, Foster WA et al. The effects of catchment and riparian forest quality on stream environmental conditions across a tropical rainforest and oil palm landscape in Malaysian Borneo. Ecohydrology 2017; 10(4): 1-14. http://dx.doi. org/10.1002/eco.1827. PMid:28706573.

Medjibe VP, Putz FE, Starkey MP, Ndouna AA, Memiaghe HR. Impacts of selective logging on above-ground forest biomass in the Monts de Cristal in Gabon. Forest Ecology and Management 2011; 262(9): 1799-1806. http://dx.doi. org/10.1016/j.foreco.2011.07.014.

Miller SD, Goulden ML, Hutyra LR, Keller M, Saleska SR, Wofsy SC et al. Reduced impact logging minimally alters tropical rainforest carbon and energy exchange. Proceedings of the National Academy of Sciences of the United States of America 2011; 108(48): 19431-19435. http://dx.doi. org/10.1073/pnas.1105068108. PMid:22087005.

Oliveira AT Fo. Classificação das fitofisionomias da América do Sul. Rodriguésia 2009; 60: 237-258.

Pan Y, Birdsey RA, Fang J, Houghton R, Kauppi PE, Kurz WA et al. A large and persistent carbon sink in the world's forests. Science 2011; 333(6045): 988-993. http://dx.doi. org/10.1126/science.1201609. PMid:21764754.

Pfeifer M, Gonsamo A, Woodgate W, Cayuela L, Marshall AR, Ledo A et al. Tropical forest canopies and their relationships with climate and disturbance: results from a global dataset of consistent field-based measurements. Forest Ecosystems 2018; 5(1): 1-14. http://dx.doi.org/10.1186/ s40663-017-0118-7.

Pfeifer M, Kor L, Nilus R, Turner E, Cusack J, Lysenko I, et al. Mapping the structure of Borneo's tropical forests across a degradation gradient. Remote Sensing of Environment 2016; 176:84-97.

Piayda A, Dubbert M, Werner C, Correia AV, Pereira JS, Cuntz M. Influence of woody tissue and leaf clumping on vertically resolved leaf area index and angular gap probability estimates. Forest Ecology and Management 2015; 340: 103-113. http://dx.doi.org/10.1016/j.foreco.2014.12.026.

Putz FE, Sist P, Fredericksen T, Dykstra D. Reduced-impact logging: challenges and opportunities. Forest Ecology and Management 2008; 256(7): 1427-1433. http://dx.doi. org/10.1016/j.foreco.2008.03.036.

Putz FE, Zuidema PA, Synnott T, Peña-Claros M, Pinard MA, Sheil D et al. Sustaining conservation values in selectively logged tropical forests: the attained and the attainable. Conservation Letters 2012; 5(4): 296-303. http:// dx.doi.org/10.1111/j.1755-263X.2012.00242.x.

Rich PM. Characterizing plant canopies with hemispherical photographs. Remote Sensing Reviews 1990; 5(1): 13-29. http://dx.doi.org/10.1080/02757259009532119.

Rockwell CA, Kainer KA, Staudhammer CL, Baraloto C. Future crop tree damage in a certified community forest in southwestern Amazonia. Forest Ecology and Management 2007; 242(2-3): 108-118. http://dx.doi.org/10.1016/j. foreco.2006.12.028.

Schleppi P, Conedera M, Sedivy I, Thimonier A. Correcting non-linearity and slope effects in the estimation of the leaf area index of forests from hemispherical photographs. Agricultural and Forest Meteorology 2007; 144(3-4): 236242. http://dx.doi.org/10.1016/j.agrformet.2007.02.004.

Schulze M, Zweede J. Canopy dynamics in unlogged and logged forest stands in the eastern Amazon. Forest Ecology and Management 2006; 236(1): 56-64. http:// dx.doi.org/10.1016/j.foreco.2006.08.333.

Siminski A, Fantini AC. A Mata Atlântica cede lugar a outros usos da terra em Santa Catarina, Brasil. Biotemas 2010; 23(2): 51-59.

Van Der Hout P. Reduced impact logging in the Tropical Rain Forest of Guyana. Georgetown: Guyona; 1999.

Vibrans AC, McRoberts RE, Moser P, Nicoletti AL. Using satellite image-based maps and ground inventory data to estimate the area of the remaining Atlantic forest in the Brazilian state of Santa Catarina. Remote Sensing of Environment 2013; 130: 87-95. http://dx.doi.org/10.1016/j. rse.2012.10.023.

Walter JMN, Torquebiau EF. The computation of forest leaf area index on slope using fisheye sensors. Comptes Rendus de l'Academie des Sciences. Serie III, Sciences de la Vie 2000; 323(9): 801-813. http://dx.doi.org/10.1016/ S0764-4469(00)01229-4. PMid:11072625.

Weiss M, Baret F. CAN_EYE. Version 6.3.8. Villenaved'Ornon: EMMAH; 2010.

Zheng G, Moskal LM. Retrieving Leaf Area Index (LAI) using remote sensing: theories, methods and sensors. Sensors (Basel) 2009; 9(4): 2719-2745. http://dx.doi. org/10.3390/s90402719. PMid:22574042.

Zuur AF, Ieno EN, Elphick CS. A protocol for data exploration to avoid common statistical problems. Methods in Ecology and Evolution 2010; 1(1): 3-14. http://dx.doi. org/10.1111/j.2041-210X.2009.00001.x. 